\title{
Monotheism in Late Prophetic and Early Apocalyptic Literature
}

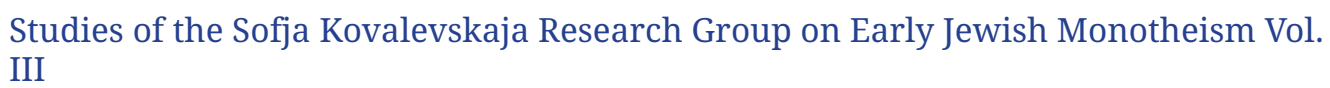

\author{
Ed. by Nathan MacDonald and Ken Brown
}

[Monotheismus in später prophetischer und früher apokalyptischer Literatur. Studien der Sofja- Kovalevskaja Forschungsgruppe zu frühjüdischem Monotheismus Band III.]

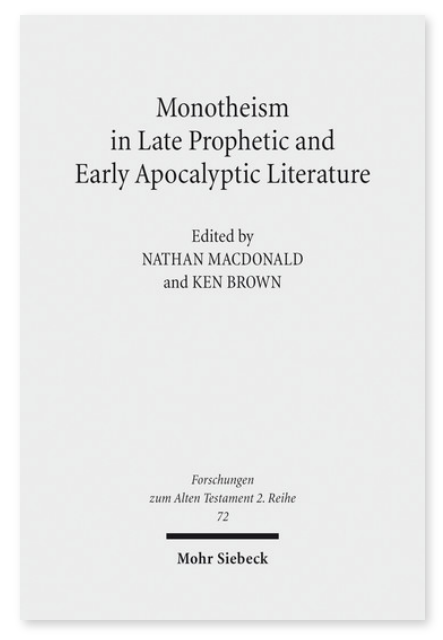

2014. XVII, 268 Seiten. FAT II 72

ISBN 978-3-16-153688-5

DOI 10.1628/978-3-16-153688-5 eBook PDF $94,00 €$

ISBN 978-3-16-153240-5

fadengeheftete Broschur 94,00€
Veröffentlicht auf Englisch.

Wissenschaftliche Diskussionen über den frühen jüdischen Monotheismus haben sich meistens auf seinen Ursprung in der früheren israelitischen Religion konzentriert, während seine Entwicklung in der späten prophetischen und frühen apokalyptischen Literatur seltener untersucht wurde. Doch das Konzept des Monotheismus spiegelt sich in dieser Literatur auf weitaus vielfältigere Weise wider als bisher bemerkt. Sie reflektiert eine lebhafte Debatte über die Auswirkungen des Glaubens an einen Gott, welche sich über ein breites Spektrum von religiösen und sozial-politischen Erfahrungen erstreckt. Die Autoren dieses Bands untersuchen diese Vielfalt, indem sie bestimmte Texte und Themen aus der persischen und hellenistischen Zeit untersuchen. Sie behandeln verschiedene Themengebiete, von der Beziehung zwischen Monotheismus und göttlicher Gewalttätigkeit zu Dualismus, vom Völkerrecht zur Idolatrie. Sie zeigen, dass nicht nur JHWHs Vorherrschaft unterschiedlich verstanden wurde, sondern dass für ihr Verständnis eine Vielfalt methodischer Ansätze notwendig ist.

\section{Inhaltsübersicht}

Ken Brown/Nathan MacDonald: Introduction - Ulrich Berges/Bernd Obermayer: Divine Violence in the Book of Isaiah - Bernd Schipper: 'The City by the Sea will be a Drying Place': Isaiah 19.1-25 in Light of Prophetic Texts from Ptolemaic Egypt - Mark S. Gignilliat: Who is a God like You? Refracting the One God in Jonah, Micah and Nahum - Lena-Sofia Tiemeyer: YHWH, the Divine Beings and Zechariah 1-6 - Nathan MacDonald: The Beginnings of One-ness Theology in Late Israelite Prophetic Literature - Reinhard Achenbach: Monotheistischer Universalismus und frühe Formen eines Völkerrechts in prophetischen Texten Israels aus achämenidischer Zeit - Jakob Wöhrle: The God(s) of the Nations in Late Prophecy - John J. Collins: Cognitive Dissonance and Eschatological Violence: Fantasized Solutions to a Theological Dilemma in Second Temple Judaism Stefan Beyerle: Monotheism, Angelology, and Dualism in Ancient Jewish Apocalyptic Writings - Jennie Grillo: Worship and Idolatry in the Book of Daniel through the Lens of Tertullian's De idololatria

Ken Brown Born 1982; 2010 MA in Biblical Studies; 2014 Dr. theol. at Georg-August-Universität Göttingen; currently teaching at Whitworth University (Spokane, WA, USA).

Nathan MacDonald Born 1975; studied theology and classical Hebrew in Cambridge and Durham; currently University Lecturer in Hebrew Bible at the University of Cambridge and Fellow of St John's College.

Jetzt bestellen:

https://mohrsiebeck.com/buch/monotheism-in-late-prophetic-and-early-apocalyptic-literature-9783161536885?no_cache=1 order@mohrsiebeck.com

Telefon: +49 (0)7071-923-17

Telefax: +49 (0)7071-51104 